\title{
Analisis Risk Profile dan Pengaruhnya Terhadap Tingkat Pengembalian Aset pada Perusahaan Perbankan BUMN yang Terdaftar Di Bursa Efek Indonesia Periode 2015 - 2019
}

\author{
Muhammad Ridho Almuhdhor \\ Fakultas Pascasarjana Magister Manajemen Universitas Jambi \\ Correspondence email: ridhoa9@gmail.com
}

\begin{abstract}
Abstrak. Penelitian ini bertujuan menganalisis bagaimana tingkat risk profile perusahaan perbankan BUMN Periode 2015-2019 dan menguji bagaimana pengaruhnya terhadap tingkat pengembalian aset secara simultan dan parsial. Penelitian ini menggunakan teknik sensus yaitu menjadikan seluruh perusahaan perbankan BUMN Periode 2015-2019 sebagai sampel penelitian. Dengan menggunakan alat analisis regresi linear berganda dan pengujian statistik secara overall (uji F) dan parsial (uji t), dapat di simpulkan bahwa berdasarkan tingkat risk profile perusahaan perbankan BUMN Periode 2015-2019, dimana Risiko Kredit menunjukkan perbankan BUMN pada kriteria sehat, Risiko Pasar dan Risiko Operasional menunjukkan perbankan BUMN pada kriteria sangat sehat sedangkan Risiko Likuiditas menunjukkan perbankan BUMN pada kriteria cukup sehat. Kemudian berdasarkan penelitian secara simultan Risiko Kredit, Risiko Pasar, Risiko Likuiditas dan Risiko Operasional berpengaruh positif signifikan terhadap tingkat pengembalian aset, sedangkan secara parsial Risiko Kredit berpengaruh negatif tidak signifikan, Risiko Pasar dan Risiko Likuiditas berpengaruh positif signifikan sedangkan Risiko Operasional berpengaruh negatif signifikan terhadap tingkat pengembalian aset.
\end{abstract}

Kata Kunci: Return On Asset, Non Performing Loan, Net Interest Margin, Loan To Deposit Ratio, BOPO

\begin{abstract}
This study aims to analyze how the risk profile level of state-owned banking companies in the period 2015-2019 and test how it affects the rate of return of assets simultaneously and partially. This study uses census techniques that make all stateowned banking companies in the period 2015-2019 as a sample of research. By using multiple linear regression analysis tools and overall statistical testing ( $F$ test) and partial ( $t$ test), it can be concluded that based on the risk profile level of state-owned banking companies in the period 2015-2019, where Credit Risk shows state-owned banks on healthy criteria, Market Risk and Operational Risk shows state-owned banks on very healthy criteria while Liquidity Risk shows state-owned banks on fairly healthy criteria. Then based on simultaneous research Credit Risk, Market Risk, Liquidity Risk and Operational Risk have a significant positive effect on the return of assets, while partially Credit Risk has a negative effect insignificant, Market Risk and Liquidity Risk have a significant positive effect while Operational Risk has a significant negative effect on the return rate of assets.
\end{abstract}

Keywords: Return On Asset, Non Performing Loan, Net Interest Margin, Loan To Deposit Ratio, BOPO

\section{Pendahuluan}

Bank adalah badan usaha yang menghimpun dana dari masyarakat dalam bentuk simpanan dan menyalurkannya ke masyarakat dalam bentuk kredit atau bentuk-bentuk lainnya dalam rangka meningkatkan taraf hidup rakyat banyak. Perbankan harus maksimal dalam mengelola agar selalu memperoleh keuntungan dan terhindar dari segala bentuk kerugian. Kerugian yang dialami perbankan dapat berpengaruh terhadap kesehatan bank itu sendiri. Bank yang tidak sehat tidak hanya membahayakan perbankan itu sendiri tetapi juga membahayakan pihak-pihak terkait lainnya. Return on Asset (ROA) adalah rasio yang digunakan untuk mengukur kemampuan manajemen bank dalam memperoleh suatu keuntungan berdasarkan asset yang dimiliki oleh bank tersebut. ROA sebuah bank seharusnya selalu mengalami peningkatan secara signifikan dari waktu ke waktu. ROA menjadi tolak ukur profitabilitas sesuai dengan harapan Bank Indonesia sebagai pembina dan pengawas perbankan yang menginginkan perolehan laba diukur dari besarnya simpanan masyarakat. Makin besar Tingkat ROA bank makin baik pula posisi bank dalam menggunakan aset dan perolehan laba operasionalnya.

Namun dalam prakteknya sangat banyak faktor yang mempengaruhi keberhasilan perbankan dalam memperoleh laba, diantara faktor yang berpengaruh adalah adanya tingkat risiko yang dihadapi oleh perbankan dalam menjalankan operasionalnya. Dari banyaknya jenis bank umum yang ada di Indonesia, Bank umum BUMN lebih banyak diminati oleh masyarakat sebagai tempat untuk menyimpan atau menginvestasikan dana yang mereka miliki karena dianggap lebih aman dan terpercaya karena dimiliki oleh negara. ROA sebuah bank seharusnya selalu mengalami peningkatan secara signifikan dari waktu ke waktu. Namun tidak demikian yang terjadi pada perbankan BUMN periode 2015-2019 dimana rata-rata perkembangan ROA selama 5 tahun periode penelitian mengalami fluktuasi dengan kecendrungan menurun sebesar $4,31 \%$. 
Hal ini tentunya tidak sejalan dengan apa yang dikemukakan oleh Rivai (2013) bahwa ROA sebuah bank seharusnya selalu mengalami peningkatan secara signifikan dari waktu ke waktu. Kecendrungan perkembangan yang cendrung menurun ini diduga dipengaruhi oleh tingkat risk profile yang dihadapi oleh perbankan BUMN. Penilaian faktor risk profile adalah penilaian terhadap risiko inheren dan kualitas penerapan manajemen risiko dalam aktivitas operasional bank. Penilaian risiko inheren adalah penilaian atas risiko yang melekat pada kegiatan bisnis bank, baik yang dapat di kuantifikasikan maupun yang tidak, yang berpotensi mempengaruhi posisi keuangan bank. Sejalan dengan hal tersebut di atas sebagaimana diungkapkan oleh Mosey dkk (2018) dalam penelitian tersebut dinyatakan risiko perbankan dapat mengancam kelangsungan hidup bank, bank wajib menerapkan manajemen risiko perbankan secara efektif. Manajemen risiko perbankan merupakan metode yang digunakan perusahaan untuk mengendalikan risiko sehingga dapat meminimalisir kerugian. Terdapat 8 jenis risiko perbankan, yaitu: Risiko Kredit, Risiko Pasar, Risiko Likuiditas, Risiko Operasional, Risiko Hukum, Risiko Reputasi, Risiko Stratejik dan Risiko Kepatuhan.

Dalam penelitian tersebut Mosey dkk hanya berfokus pada risiko pasar dan risiko kredit. Untuk mengembangkan penelitian tersebut maka penulis menggali risiko perbankan di pandang dari seluruh aspek finansial yaitu tidak hanya meneliti risiko pasar dan risiko kredit. Adapun risiko perbankan yang dikatagorikan risiko finansial adalah Risiko usaha yang dapat diukur dengan menggunakan laporan keuangan Bank. Cahyani, Herizon, (2020) menyatakan bahwa yang tergolong risiko yang dapat diukur dengan menggunakan laporan keuangan bank adalah Risiko Kredit, Risiko Pasar, Risiko Likuiditas dan Risiko Operasional. Hal ini sejalan dengan proksi Return On Asset sebagai ukuran tingkat profitabilitas yang ditinjau dari perolehan aset operasional dalam mencipkaan laba operasional. Risk profile sebagai pendekatan dalam melihat Tingkat kesehatan bank, untuk menilai hal ini dapat dinilai dari beberapa indikator. Salah satu sumber utama indikator yang dijadikan dasar penilaian adalah laporan keuangan bank yang bersangkutan. Laporan keuangan adalah laporan yang menunjukkan kondisi keuangan perusahaan pada saat ini atau dalam suatu periode tertentu (Kasmir, 2014). Laporan keuangan dibuat dengan maksud untuk memberikan gambaran atau laporan kemajuan yang secara periodik dilakukan pihak manajemen perusahaan yang bersangkutan. Dengan kata lain laporan keuangan bertujuan untuk menyediakan informasi yang menyangkut posisi keuangan, kinerja serta perubahan posisi keuangan suatu perusahaan yang bermanfaat bagi sejumlah besar pemakainya dalam pengambilan keputusan. Dari laporan keuangan akan terbaca bagaimana kondisi bank yang sesungguhnya, termasuk kelemahan dan kekuatan yang dimiliki. Menurut menteri BUMN untuk transparansi anggaran (Rini Soemarno, 2019), menjelaskan Bank Umum BUMN selalu mengalami kredit bermasalah, atau setiap tahun kredit bermasalah selalu meningkat, Tumbuhnya total kredit perbankan yang macet atau tidak lancar dapat dilihat dari keempat bank umum BUMN. Munculnya kredit macet dipengaruhi banyak faktor diantaranya adanya nasabah yang tidak jujur. Selain itu kredit macet muncul karena pada saat pengucuran kredit terjadi, Account Officer tidak melakukan pengecekan pengajuan kredit dengan benar sesuai tugas dan fungsi yang diemban dan dikonfirmasi atas data dokumen yang dilampirkan dalam pengajuan kredit, sehingga kredit lolos untuk disetujui. Setelah kredit dikucurkan, dalam pembayarannya kredit tersebut macet karena pihak nasabah tidak mampu lagi memenuhi kewajibannya untuk membayar fasilitas kredit yang telah diterima baik berupa kredit pokok maupun bunga. Gambaran kredit macet ini merupakan bagian dari risiko kredit perbankan. Dilihat dari persentase perkembangannya, selama 5 tahun periode penelitian NPL perusahaan perbankan BUMN berfluktusasi dengan kecendrungan meningkat sebesar 3,84\%.

Hal ini menunjukkan indikasi kinerja yang kurang baik, karena NPL yang makin tinggi menunjukkan makin besarnya tingkat kredit macet pada perbankan. Risiko berikutnya dari risk profile adalah risiko pasar. Risiko Pasar yang terjadi akibat pengaruh harga pasar salah satunya dapat dilihat dari bagaimana pengaruh tingkat bunga terhadap pendapatan perusahaan yang dicerminkan pada besarnya rasio Net Interest Margin ( NIM ), selama 5 tahun terakhir rasio Net Interest Margin (NIM) berfluktuasi dengan kecendrungan menurun dengan rata-rata penurunan 3,68\%, Kecendrungan penurunan NIM mengindikasikan kinerja yang kurang baik karena berarti risiko pasar berpengaruh negatif terhadap operasional perusahaan yang tercermin pada tingkat pengambalian aset bagi perusahaan. Makin rendah NIM artinya pendapatan Bank makin menurun. Risiko berikutnya yang menjadi bagian dari risk profile finansial adalah risiko likuiditas yang dicerminkan pada besarnya rasio keuangan Loan to Deposit Ratio.

Indikasi berfluktuasinya LDR menunjukkan kemampuan Bank dalam membayar kewajiban yang jatuh tempo pada pihak ketiga dengan mengandalkan kredit yang disalurkan bank juga berfluktuasi. Meskipun LDR perusahaan perbankan BUMN mengalami kenaikan, namun persentase peningkatannya cendrung menurun. Dalam hal ini perlu menjadi perhatian pada perusahaan perbankan, dimana jika semakin rendah LDR ini artinya semakin tinggi likuiditas bank BUMN. Namun sebaliknya jika semakin tinggi LDR ini maka semakin rendah likuiditas bank BUMN. Risiko berikutnya yang menjadi bagian dari risk profile finansial adalah risiko operasional. Risiko operasional tercermin didalam biaya operasional terhadap pendapatan operasional (BOPO), Rata-rata Beban Operasional Pendapatan Operasional (BOPO) selama 5 tahun penelitian menunjukkan tingkat yang berfluktuasi dengan kecendrungan meningkat dengan rata-rata perkembangan $0,78 \%$. Dalam hal ini perlu menjadi perhatian pada perusahaan perbankan konvensional yang menghimpun dana dari masyarakat dan menyalurkannya kembali dalam bentuk kredit, sehingga 
beban bunga dan hasil Bunga bagi perbankan BUMN merupakan porsi terbesar bagi Bank, Jika rasio BOPO meningkat mengindikasikan kinerja yang kurang baik, karena makin tinggi perbandingan antara biaya dengan pendapatan operasional bank tersebut.

Dengan memperhatikan keseluruhan fakta yang muncul pada aspek-aspek risiko yaitu risiko kredit, risiko pasar, risiko likuiditas dan risiko operasional terlihat adanya indikasi yang kurang baik, yang pada gilirannya akan mempengaruhi operasional perusahaan yang akan berpengaruh pada kinerja perbankan yang dapat dilihat dari Tingkat Pengembalian Aset perusahaan atau yang dikenal juga dengan Return On Asset perusahaan perbankan yang menjadi tolak ukur profitabilitas sesuai dengan harapan Bank Indonesia sebagai pembina dan pengawas perbankan yang menginginkan perolehan laba diukur dari besarnya simpanan masyarakat. Kemudian peneliti menjadikan penelitian terdahulu sebagai pendukung penelitian sekarang seperti Buchory (2015) menyatakan bahwa variabel LDR, BOPO, dan NPL berpengaruh signifikan terhadap ROA, kemudian Korompis (2020) menyatakan bahwa variabel NIM, NPL, dan LDR berpengaruh signifikan terhadap ROA, dan selanjutnya Setiono \& Sukirno (2018) menyatakan bahwa variabel CAR, LDR, dan NIM berpengaruh signifikan terhadap ROA. Berdasarkan hal tersebut penulis tertarik mengkaji lebih mendalam mengenai aspek risk profile yang terkait dengan risiko finansial dan menganalisis pengaruhnya terhadap Return On Asset perusahaan perbankan BUMN yang terdaftar di BEI pereode 2015-2019. Tujuan dari penelitian ini adalah Untuk menganalisis bagaimana tingkat Risk Profile perusahaan Perbankan BUMN yang terdaftar di BEI periode 2015-2019 dilihat dari aspek Risiko Kredit, Risiko Pasar, Risiko Likuiditas dan Risiko Operasional, untuk menguji bagaimana Pengaruh Risiko Kredit, Risiko Pasar, Risiko Likuiditas dan Risiko Operasional secara simultan Terhadap Tingkat Pengembalian Aset perusahaan Perbankan BUMN periode 2015-2019, untuk menguji bagaimana pengaruh Risiko Kredit, Risiko Pasar, Risiko Likuiditas dan Risiko Operasional secara parsial terhadap Tingkat Pengembalian Aset perusahaan Perbankan BUMN periode 2015-2019.

\section{Metode}

Populasi dan Sampel adalah Perbankan BUMN Periode 2015-2019, peneliti menggunakan teknik sensus dimana seluruh objek dalam penelitian sebagai sampel. Jenis data adalah data sekunder dimana data yang tidak langsung memberikan data kepada pengumpul data. Sumber data dikumpulkan berupa laporan tahunan perusahaan perbankan BUMN yang terdaftar di Bursa Efek Indonesia. Metode pengumpulan data menggunakan penelitian kepustakaan dimana metode pengumpulan data dengan cara membaca buku pustaka, referensi serta hasil dari penelitian terdahulu, agar diperoleh pengetahuan tentang yang diteliti sehingga dapat memecahkan masalah penelitian dengan cara yang tepat. Hasil dari regrasi linear berganda, di dukung dengan pengujian asumsi klasik untuk menguji kelayakan data yaitu Uji Normalitas, Uji Multikolinearitas, Uji Heteroskedastisitas dan Uji Autokorelasi. Metode penelitian ini adalah metode deskriptif kuantitatif. Alat analisis yang digunakan dalam penelitian ini yaitu regresi linear berganda, Kemudian untuk pengujian hipotesis dilakukan Uji F, Uji t dan Koefisien Determinasi ( $\left.\mathrm{R}^{2}\right)$.

\section{Hasil}

Tabel 1

Perkembangan Tingkat Risiko Kredit Perusahaan Perbankan BUMN Periode 2015 - 2019

\begin{tabular}{|l|r|r|r|r|r|r|}
\hline \multicolumn{1}{|c|}{ Keterangan } & \multicolumn{1}{c|}{$\mathbf{2 0 1 5}$} & \multicolumn{1}{c|}{$\mathbf{2 0 1 6}$} & \multicolumn{1}{c|}{$\mathbf{2 0 1 7}$} & \multicolumn{1}{c|}{$\mathbf{2 0 1 8}$} & \multicolumn{1}{c|}{$\mathbf{2 0 1 9}$} & \multicolumn{1}{c|}{ Rata-rata } \\
\hline Rata-rata NPL (\%) & 2,61 & 2,96 & 2,63 & 2,41 & 3,02 & 2,73 \\
\hline Kinerja Perusahaan Perbankan & Sehat & Sehat & Sehat & Sehat & Sehat & Sehat \\
\hline Matriks Penilaian & \multicolumn{6}{l}{ Surat Edaran Bank Indonesia No 6/23/DPNP/2014 Berada Pada Kriteria (2\% - 3,5\%) } \\
\hline
\end{tabular}

Sumber: Data diolah

Berdasarkan Tabel diatas dapat dilihat bahwa selama periode penelitian Risiko kredit dengan indikator Non Performing Loan (NPL) perusahaan Perbankan BUMN berada dalam katagori sehat. NPL terendah terjadi di tahun 2018 sedangkan NPL tertinggi terjadi di tahun 2019. Berdasarkan katagori yang ditetapkan oleh Surat Edaran Bank Indonesia No 6 /23/DPNP/2014 berada pada kriteria dengan komposisi NPL diantara 2\% < 3,5\% maka perusahaan perbankan BUMN berada dalam kriteria sehat. Dengan demikian tingkat Risiko Kredit perusahaan perbankan BUMN selama periode penelitian secara umum dapat dinyatakan dalam kondisi sehat.

Tabel 2

Perkembangan Risiko Pasar Pada Perusahaan Perbankan BUMN Periode 2015 - 2019

\begin{tabular}{|l|c|c|c|c|c|c|}
\hline \multicolumn{1}{|c|}{ Keterangan } & $\mathbf{2 0 1 5}$ & $\mathbf{2 0 1 6}$ & $\mathbf{2 0 1 7}$ & $\mathbf{2 0 1 8}$ & $\mathbf{2 0 1 9}$ & Rata-rata \\
\hline Rata-rata NIM (\%) & 6,26 & 6,37 & 5,96 & 5,65 & 5,17 & 5,88 \\
\hline Kinerja Perusahaan Perbankan & Sangat Sehat & Sangat Sehat & Sangat Sehat & Sangat Sehat & Sangat Sehat & Sangat Sehat \\
\hline Matriks Penilaian & Surat Edaran Bank Indonesia No 6/23/DPNP/2014 Berada Pada Kriteria (NIM $>5 \%)$ \\
\hline
\end{tabular}

Sumber: Data diolah 
Berdasarkan data pada tabel di atas, selama periode penelitian Perusahaan Perbankan BUMN dillihat dari kinerjanya berdasarkan aspek risiko pasar menunjukkan kinerja perusahaan yang sangat sehat dimana kinerja dari setiap tahun selama periode penelitian berada pada kriteria Net Interest Margin (NIM) $>5 \%$. Rata-rata Risiko Pasar berada pada posisi 5,88 \% Artinya Perbankan BUMN dalam kondisi sangat sehat.

Tabel 3

Perkembangan Risiko Likuiditas (LDR) Pada Perusahaan Perbankan BUMN Periode 2015 - 2019

\begin{tabular}{|l|c|c|r|r|r|r|}
\hline \multicolumn{1}{|c|}{ Keterangan } & $\mathbf{2 0 1 5}$ & $\mathbf{2 0 1 6}$ & $\mathbf{2 0 1 7}$ & $\mathbf{2 0 1 8}$ & $\mathbf{2 0 1 9}$ & Rata-rata \\
\hline Rata-rata LDR (\%) & 92,63 & 91,67 & 91,24 & 94,59 & 97,50 & 93,53 \\
\hline Kinerja Perusahaan Perbankan & Cukup Sehat & Cukup Sehat & Cukup Sehat & Cukup Sehat & Cukup Sehat & Cukup Sehat \\
\hline Matriks Penilaian & \multicolumn{6}{l}{ Surat Edaran Bank Indonesia No 6/23/DPNP/2014 Berada Pada Kriteria $(85 \%-100 \%)$} \\
\hline
\end{tabular}

Sumber: Data diolah

Berdasarkan tabel diatas dapat diketahui selama periode penelitian risiko likuiditas yang ditunjukkan dengan Loan to Deposit Ratio (LDR) perusahaan perbankan menunjukkan tingkat yang cukup sehat, dengan tingkat rata-rata LDR 95,53\%. Tingkat LDR terendah 91,24\% pada tahun 2017 dan tertinggi pada tahun 2019 yaitu sebesar 97,5\%. Berdasarkan hal tersebut maka dapat dinyatakan berdasarkan kriteria Surat Edaran Bank Indonesia No. 6 /23/DPNP/2014 yang menetapkan kinerja perusahaan berada dalam katagori cukup sehat jika dilihat dari aspek likuiditas karena berada pada kisaran LDR $85 \%$ - $100 \%$.

Tabel 4

Perkembangan Risiko Operasional (BOPO) pada Perusahaan Perbankan BUMN Periode 2015 -2019

\begin{tabular}{|l|c|c|c|c|c|c|}
\hline \multicolumn{1}{|c|}{ Keterangan } & 2015 & 2016 & 2017 & 2018 & 2019 & Rata-rata \\
\hline Rata-rata BOPO (\%) & 74,49 & 76,49 & 73,50 & 72,69 & 77,22 & 74,87 \\
\hline Kinerja Perushaan Perbankan & Sangat Sehat & Sangat Sehat & Sangat Sehat & Sangat Sehat & Sangat Sehat & Sangat Sehat \\
\hline Matriks Penilaian & \multicolumn{6}{l}{ Surat Edaran Bank Indonesia No 6/23/DPNP/2014 Berada Pada Kriteria (BOPO <90\%) } \\
\hline
\end{tabular}

Sumber: Data diolah

Berdasarkan Tabel 4 di atas dapat diketahui bahwa rata-rata BOPO berada pada tingkat $74,87 \%$, hal ini menunjukkan bahwa kinerja perusahaan perbankan BUMN berada dalam kategori sangat sehat karena berdasarkan Surat Edaran Bank Indonesia No 6 /23/DPNP/2014 berada pada kriteria katagori < $90 \%$. Hasil uji normalitas, dari Gambar 1 Normal P-Plot of Regression Standardized Residual terlihat bahwa titik-titik menyebar di sekitar garis diagonal dan mengikuti arah garis diagonal (tidak berpencar jauh dari garis lurus), hal ini menunjukan bahwa model regresi layak dipakai karena memenuhi asumsi normalitas data berdistribusi normal, karena titik dalam gambar menyebar di sekitar garis diagonal dan arahnya mengikuti garis diagonal.

\section{Gambar 1}

Normal P-Plot of Regression Standardized Residual Normal P.P Plot of Regression Standardized Residual

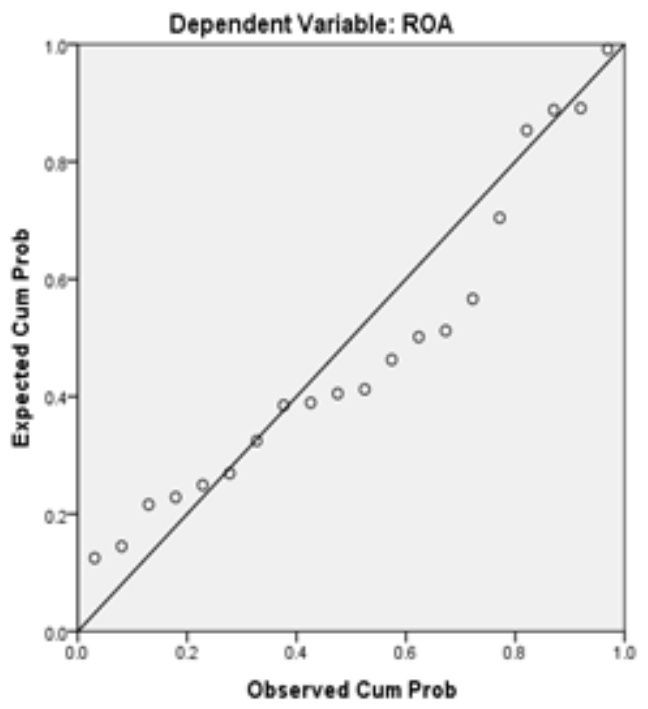

Sumber: Data diolah 
Muhammad Ridho Almuhdhor, Analisis Risk Profile dan Pengaruhnya Terhadap Tingkat Pengembalian Aset pada Perusahaan Perbankan BUMN yang Terdaftar Di Bursa Efek Indonesia Periode 2015 - 2019

Tabel 5

Hasil Uji Multikoliniarity

\begin{tabular}{|c|c|c|c|c|c|c|}
\hline \multirow{2}{*}{\multicolumn{2}{|c|}{ Model }} & \multicolumn{3}{|c|}{ Correlation } & \multicolumn{2}{|c|}{ Collinearity Statistics } \\
\hline & & Zero-order & Partial & Part & Tolerance & VIF \\
\hline \multirow{4}{*}{1} & $\begin{array}{l}\text { (Constant) } \\
\text { NPL }\end{array}$ & -.767 & -.278 & -.034 & 377 & 2.649 \\
\hline & NIM & .882 & .935 & .310 & .412 & 2.425 \\
\hline & LDR & -.780 & .505 & .069 & .299 & 3.341 \\
\hline & BOPO & -.939 & -.930 & -.296 & .203 & 4.929 \\
\hline
\end{tabular}

Sumber: Data diolah

Berdasarkan Tabel 5 hasil uji multikolinearitas di atas dapat diketahui bahwa nilai Tolerance dari Variabel Independen yaitu variance influence factor (VIF) NPL adalah 2,649, VIF NIM sebesar 2,425, VIF LDR 3,341 dan VIF BOPO 4,929 menunjukan nilai Tolerance diatas 0,1 dan nilai VIF dibawah 10 Oleh karena itu dapat disimpulkan bahwa tidak ada multikolinearitas antara variabel independen dalam model regresi.

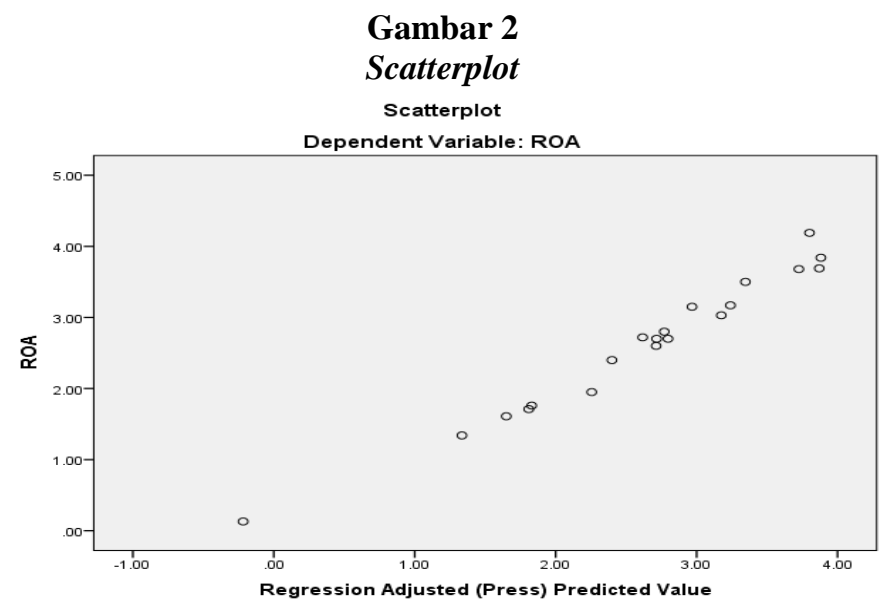

Sumber: Data diolah

Gambar 2 terlihat bahwa titik-titik menyebar secara acak serta tersebar baik diatas maupun dibawah angka 0 pada sumbu Y dan tidak membentuk pola tertentu. Maka dapat dinyatakan bahwa tidak terjadi heteroskedasitas pada model regresi dalam penelitian ini.

Tabel 6

Hasil Uji Autokorelasi

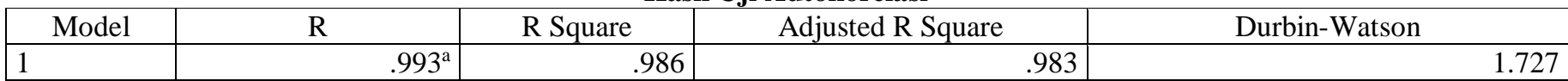

Sumber: data diolah

Berdasarkan uji yang telah dilakukan maka didapat nilai uji Durbin-Watson sebesar 1,727 (nilai tersebut terletak diantara -2 sampai 2). Dengan demikian dapat diputuskan tidak terjadi Autokorelasi pada penelitian ini.

Tabel 7

Model Analisis Regresi Linier Berganda

\begin{tabular}{|c|c|c|c|c|c|}
\hline \multirow[t]{2}{*}{ Model } & \multicolumn{2}{|c|}{ Unstandardized Coefficients } & \multirow{2}{*}{\begin{tabular}{|c|} 
Standardized Coefficients \\
Beta \\
\end{tabular}} & \multicolumn{2}{|c|}{ Collinearity Statistics } \\
\hline & $\mathrm{B}$ & Std. Error & & Tolerance & VIF \\
\hline (Constant) & 5.166 & .695 & & & \\
\hline NPL & -.076 & .068 & -.055 & .377 & 2.649 \\
\hline NIM & .377 & .037 & .483 & .412 & 2.425 \\
\hline LDR & .015 & .007 & .125 & .299 & 3.341 \\
\hline $\mathrm{BOPO}$ & -.079 & .008 & -.656 & .203 & 4.929 \\
\hline
\end{tabular}

Sumber: Data Diolah

Berdasarkan tabel 7 diatas dapat dirumuskan model regresi linier berganda sbb:

$Y=5,166-0,076 X_{1}+0,377 X_{2}+0,015 X_{3}-0,079 X_{4}$ 
dimana: $\mathrm{Y}=$ Return On Asset $(\mathrm{ROA}) ; \mathrm{X}_{1}=$ Non Performing Loan (NPL); $\mathrm{X}_{2}=$ Net Interest Margin (NIM); $\mathrm{X}_{3}=$ Loan to Deposti Ratio $(\mathrm{LDR}) ; \mathrm{X}_{4}=$ Beban Operasional Pendapatan Operasional $(\mathrm{BOPO}) ; \mathrm{a}=$ Konstanta

Berdasarkan model tersebut dapat dinterprestasikan model regresi linier berganda sbb:

- Koefisien Konstanta sebesar 5,166 artinya jika faktor-faktor yang mempengaruhinya dianggap konstan maka besarnya ROA adalah 5,166;

- Koefisien Regresi $X_{1}\left(B_{1}\right)$ sebesar - 0,076. artinya jika Risiko kredit berpengaruh negatif terhadap ROA. Besar koefisien pengaruhnya adalah 0,076 artinya jika Risiko kredit naik $1 \%$ dengan asumsi faktor-faktor yang lain tetap maka ROA akan menurun $0,076 \%$ demikian pula sebaliknya, jika risiko kredit menurun $1 \%$ maka ROA akan meningkat $0,076 \%$

- Koefisien Regresi $\mathrm{X}_{2}\left(\mathrm{~B}_{2}\right)$ sebesar 0,377, artinya Risiko Pasar berpengaruh positif terhadap ROA . Besar koefisien pengaruhnya 0,377 artinya jika Risiko Pasar mengalami kenaikan 1\% maka ROA akan meningkat $0,377 \%$ demikian pula sebaliknya, jika Risiko Pasar mengalami penurunan $1 \%$ maka ROA akan menurun $0,377 \%$ asumsi factor-faktor lain yang mempengaruhinya tetap.

- Koefisien Regresi $\mathrm{X}_{3}$ ( $\mathrm{B}_{3}$ ) sebesar 0,015, artinya Risiko likuiditas berpengaruh positif terhadap ROA. Besar koefisien pengaruhnya adalah 0,015 , jika Risiko Likuiditas mengalami kenaikan $1 \%$ dengan asumsi faktor-faktor yang lain tetap maka ROA akan meningkat $0,015 \%$ demikian pula sebaliknya, jika risiko Likuiditas menurun $1 \%$ maka ROA akan menurun $0,015 \%$ dengan asumsi faktor-faktor yang mempengaruhinya tetap.

- Koefisien Regresi $\mathrm{X}_{4}\left(\mathrm{~B}_{4}\right)$ sebesar - 0,079. artinya Risiko operasional berpengaruh negatif terhadap ROA. Besar koefisien pengaruhnya adalah 0,079 , jika Risiko Operasional mengalami kenaikan $1 \%$ dengan asumsi faktorfaktor yang lain tetap maka ROA akan menurun 0,079\%. Demikian pula sebaliknya, jika risiko operasional menurun $1 \%$ maka ROA akan meningkat $0,079 \%$

Tabel 8

Uji F Statistik

\begin{tabular}{|ll|r|r|r|r|}
\hline \multicolumn{1}{|c|}{ Model } & Sum of Squares & Df & Mean Square & F & \multicolumn{1}{c|}{ Sig. } \\
\hline \multirow{4}{*}{1} & Regression & 18.467 & 4 & 4.617 & 269.719 \\
\\
Residual & .257 & 15 & .017 & $.000^{\mathrm{b}}$ \\
& Total & 18.723 & 19 & & \\
\hline
\end{tabular}

Sumber: Data Diolah

Berdasarkan tabel 8 dapat diketahui bahwa $\mathrm{F}$ hitung adalah 269,719 sedangkan besarnya $\mathrm{F}$ tabel pada derajat kebebasan n-k-1 (15) adalah 3,06. Dengan demikian maka F hitung 269,710 > F tabel 3,06 dengan demikian dapat disimpulkan bahwa secara bersama-sama NPL, NIM, LDR dan BOPO berpengaruh signifikan terhadap ROA.

Tabel 9

Uji t

\begin{tabular}{|c|c|c|c|c|c|c|}
\hline \multirow{2}{*}{\multicolumn{2}{|c|}{ Model }} & \multicolumn{2}{|c|}{ Unstandardized Coefficients } & \multirow{2}{*}{$\begin{array}{c}\text { Standardized Coefficients } \\
\text { Beta }\end{array}$} & \multirow{2}{*}{$\mathrm{t}$} & \multirow{2}{*}{ Sig. } \\
\hline & & $\mathrm{B}$ & Std. Error & & & \\
\hline \multirow{5}{*}{1} & (Constant) & 5.166 & .695 & & 7.429 & .000 \\
\hline & NPL & -.076 & .068 & -.055 & -1.120 & .280 \\
\hline & NIM & .377 & .037 & .483 & 10.249 & .000 \\
\hline & LDR & .015 & .007 & .125 & 2.269 & .038 \\
\hline & BOPO & -.079 & .008 & -.656 & -9.778 & .000 \\
\hline
\end{tabular}

Sumber: Data diolah

a. Pengaruh Risiko Kredit terhadap tingkat Pengembalian Aset

Berdasarkan tabel diatas dapat diperoleh nilai $t_{\text {hitung }}$ sebesar $-1,120$ dengan nilai sig sebesar $.0,280$. Dengan menggunakan uji 2 arah, diperoleh t-tabel 2,131 hal ini menunjukkan bahwa nilai t-hitung -1,120 lebih kecil dari pada nilai t-tabel $0,05 / 2,15(2,131)$. Dengan demikian Ho diterima dan Ha ditolak. Artinya risiko kredit tidak berpengaruh signifikan terhadap tingkat pengembalian aset pada perusahaan BUMN periode 2015-2019 .

b. Pengaruh Risiko Pasar terhadap Tingkat Pengembalian Aset

Berdasarkan tabel diatas dapat diperoleh nilai thitung sebesar 10,249 dengan nilai sig sebesar 0,00. Dengan menggunakan uji 2 arah, diperoleh t-tabel 2,131 hal ini menunjukkan bahwa nilai t-hitung 10,249 lebih besar dari pada nilai t-tabel $0,05 / 2,15(2,131)$. Dengan demikian Ho ditolak dan Ha diterima. Artinya risiko pasar berpengaruh signifikan terhadap tingkat pengembalian aset pada perusahaan BUMN periode 2015 - 2019.

c. Pengaruh Risiko Likuiditas terhadap tingkat Pengembalian Aset 
Berdasarkan tabel diatas dapat diperoleh nilai $\mathrm{t}$ hitung sebesar 2,269 dengan nilai sig sebesar 0,38 Dengan menggunakan uji 2 arah, diperoleh t-tabel 2,131 hal ini menunjukkan bahwa nilai t-hitung 2,269 lebih besar dari pada nilai t-tabel 0,05/2,15 (2,131). Dengan demikian Ho ditolak dan Ha diterima. Artinya risiko likuiditas berpengaruh signifikan terhadap tingkat pengembalian aset pada perusahaan BUMN periode 2015 - 2019.

d. Pengaruh Risiko Operasional terhadap tingkat Pengembalian Aset

Berdasarkan tabel diatas dapat diperoleh nilai $t$ hitung sebesar $-9,778$ dengan nilai sig sebesar 0,00. Dengan menggunakan uji 2 arah, diperoleh t tabel 2,131 hal ini menunjukkan bahwa nilai t-hitung - 9,778 lebih kecil dari pada nilai t-tabel $0,05 / 2,15$ ( 2,131 ). Dengan demikian Ho ditolak dan Ha diterima. Artinya risiko operasional berpengaruh signifikan terhadap tingkat pengembalian aset pada perusahaan BUMN periode 2015 - 2019.

Tabel 10

Koefisien Determinasi

\begin{tabular}{|l|r|r|r|c|}
\hline \multicolumn{1}{|c|}{ Model } & R & R Square & Adjusted R Square & Std. Error of the Estimate \\
\hline 1 & $.993^{\mathrm{a}}$ & .986 & .983 & .13083 \\
\hline
\end{tabular}

Sumber: Data Diolah

Berdasarkan hasil pengujian koefisien determinasi pada tabel diatas, menunjukkan bahwa nilai $\mathrm{R}$ Square sebesar 0.986 yang artinya bahwa besarnya kemampuan variabel independen yaitu $\mathrm{X}_{1}, \mathrm{X}_{2}, \mathrm{X}_{3}$, dan $\mathrm{X}_{4}$ menjelaskan variabel Y (Tingkat Pengembalian Aset) sebesar 98,6\% sedangkan sisanya 1,4 \% (100\% - 98,6 \%) dipengaruhi oleh variabel-variabel lain di luar penelitian ini.

Tabel 11

Perkembangan Risk Profile Perusahaan Perbankan BUMN Periode 2015-2019

\begin{tabular}{|l|l|l|r|r|l|}
\hline \multirow{2}{*}{ No } & \multirow{2}{*}{ Risk Profile } & \multirow{2}{*}{ Indikator } & \multicolumn{3}{|c|}{ Keterangan } \\
\cline { 4 - 6 } & & & Rata-rata & \multicolumn{1}{c|}{ Kriteria } & \multicolumn{1}{c|}{ Kinerja Perusahaan Perbankan } \\
\hline 1 & Risiko Kredit & NPL & 2,73 & $2 \%-3,5 \%$ & Sehat \\
\hline 2 & Risiko Pasar & NIM & 5,88 & NIM $>5 \%$ & Sangat Sehat \\
\hline 3 & Risiko Likuiditas & LDR & 93,53 & $85 \%-100 \%$ & Cukup Sehat \\
\hline 4 & Risiko Operasional & BOPO & 74,87 & BOPO $<90 \%$ & Sangat Sehat \\
\hline
\end{tabular}

Sumber: Data Diolah

Berdasarkan tabel 11 keterangan mengenai rata-rata kriteria kinerja perusahaan perbankan bersumber dari Surat Edaran Bank Indonesia No 6/23/DPNP/2014 dapat diketahui bahwa Risiko Kredit Perusahaan Perbankan BUMN dinilai sehat, dan Risiko Likuiditas cukup sehat, sedangkan Risiko Pasar dan Risiko Operasional berada dalam posisi sangat sehat. Meskipun dilatar belakang Risiko Kredit Berfluktuasi Meningkat dimana hasil rata-rata masuk ke dalam kriteria sehat, Risiko Pasar Berfluktuasi Menurun dimana hasil rata-rata masuk ke dalam kriteria sangat sehat, Risiko Likuiditas kecenderungan menurun dimana hasil rata-rata masuk kedalam kriteria cukup sehat, Risiko Operasional Berfluktuasi Meningkat dimana hasil rata-rata masuk kedalam keadaan sangat sehat, hal tersebut bisa terjadi karena adanya faktor eksternal yang bisa mempengaruhi keadaan perbankan BUMN karena Bank tersebut miliki pemerintah seperti adanya kebijakan oleh pemerintah, serta adanya kepentingan pemerintah di dalamnya. Kemudian untuk penelitian terdahulu yang dilakukan oleh Yunika (2017), Lilianti (2019), Diarto (2016) dimana berdasarkan faktor risk profile menggunakan NPL adalah berpredikat sangat baik yang menunjukkan kondisi bank sangat sehat, kemudian menggunakan LDR hasilnya adalah berpredikat baik yang menunjukkan kondisi bank sehat.

Berdasarkan hasil analisis regresi yang dilakukan di dalam penelitian ini di sertai uji statistik secara overall dengan uji F dan hasil koefisien determinasi, maka dapat disimpulkan bahwa secara bersama-sama NPL, NIM, LDR dan BOPO berpengaruh positif signifikan terhadap ROA. Hal ini ditunjukkan dengan $\mathrm{F}$ hitung adalah 269,719 pada tingkat sig $=0,000$ ( $\operatorname{sig}<0,05)$, adapun besarnya $\mathrm{F}$ tabel pada derajat kebebasan n-k-1 (15) adalah 3,06. Dengan demikian maka $\mathrm{F}$ hitung $269,710>\mathrm{F}$ tabel 3,06 , artinya menolak Ho dan menerima Ha yaitu terdapat pengaruh signifikan secara bersama-sama variabel independent (NPL, NIM, LDR dan BOPO) terhadap variabel dependent (ROA) . Hal ini dipertegas lagi dengan hasil analisis Determinasi yang menunjukkan nilai yang mendekati 1 yaitu 98,6 $\%$ yang bermakna kemampuan variabel independent secara bersama-sama mampu menjelaskan variabel dependent sebanyak 98,6\% sisanya 1,4 \% dipengaruhi oleh faktor-faktor lain diluar variabel peneltian ini. Penelitian ini sejalan dengan penelitian terdahulu secara simultan yang dilakukan oleh Buchory (2015), Korompis (2020), dan Setiono (2018) yang menyatakan bahwa risiko kredit, risiko pasar, risiko likuiditas dan risiko operasional berpengaruh positif signifikan terhadap ROA.

Secara parsial risiko kredit berpengaruh negatif tidak signifikan terhadap tingkat pengembalian aset. Hal tersebut terjadi berdasarkan nilai koefisien Beta regresi $\mathrm{X}_{1}$ sebesar - 0,076 maka dapat dimaknai terdapat pengaruh 
negatif risiko kredit terhadap ROA, dengan besar pengaruh nya 0,076. Kondisi ini menunjukkan setiap $1 \%$ kenaikan risiko kredit ceteris paribus akan berakibat penurunan ROA sebesar 0,076\%. Signifikansi besar pengaruh tersebut diuji dengan uji $\mathrm{t}$ dengan nilai $\mathrm{t}$ hitung sebesar -1,120 dengan nilai sig sebesar .0,280 Dengan menggunakan uji 2 arah, diperoleh $\mathrm{t}$ tabel 2,131 hal ini menunjukkan bahwa nilai t hitung -1,120 lebih kecil dari pada nilai t tabel $0,05 / 2,15$ $(2,131)$. Dengan demikian Ho diterima dan Ha ditolak. Artinya Risiko Kredit berpengaruh negatif tidak signifikan terhadap Tingkat Pengembalian Aset pada perusahaan BUMN periode 2015-2019. Penelitian ini tidak sejalan dengan penelitian terdahulu yang dilakukan oleh Angela (2018), Korompis (2020), dan Saeed (2015) bahwa secara parsial risiko kredit berpengaruh signifikan terhadap tingkat pengembalian aset.

Secara parsial Risiko Pasar berpengaruh positif signifikan terhadap Tingkat Pengembalian Aset pada perusahaan BUMN periode 2015 - 2019. Keadaan tersebut didasarkan atas hasil uji koefisien regresi dan uji t. Beta $\mathrm{X}_{2}$ adalah sebesar 0,377 artinya terdapat pengaruh positif risiko pasar terhadap ROA secara parsial, ceterus paribus. Jika terjadi kenaikan risiko pasar akan berakibat peningkatan pula dalam ROA sebesar 0,377\%. Hasil uji signifikan parsial

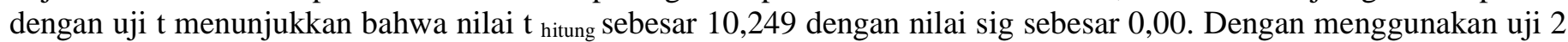
arah, diperoleh $\mathrm{t}$ tabel 2,131 hal ini menunjukkan bahwa nilai t hitung 10,249 lebih besar dari pada nilai tabel $0,05 / 2,15$ $(2,131)$. Dengan demikian Ho ditolak dan Ha diterima. Artinya Risiko Pasar berpengaruh positif signifikan terhadap Tingkat Pengembalian Aset pada perusahaan BUMN periode 2015 - 2019 . Penelitian ini sejalan dengan penelitian terdahulu yang dilakukan oleh Angela (2018), Korompis (2020), dan Setiono (2018) bahwa secara parsial risiko pasar berpengaruh positif signifikan terhadap tingkat pengembalian aset.

Secara parsial risiko likuditas berpengaruh positif signifikan terhadap Tingkat Pengembalian Aset pada perusahaan BUMN periode 2015 - 2019. Hal tersebut terlihat berdasarkan nilai koefisien Beta $\mathrm{X}_{3}$ sebesar 0,015. Artinya terdapat pengaruh positif risiko likuiditas terhadap ROA secara parsial. Jika risiko likuiditas meningkat $1 \%$ maka ROA akan meningkat $0,015 \%$ ceteris paribus. Signifikansi pengaruh secara parsial ditunjukkan oleh hasil uji t. Hasil uji $\mathrm{t}$ menunjukkan nilai $\mathrm{t}$ hitung sebesar 2,269 dengan nilai sig sebesar 0,38 Dengan menggunakan uji 2 arah, diperoleh $\mathrm{t}$ tabel 2,131 hal ini menunjukkan bahwa nilai t hitung 2,269 lebih besar dari pada nilai t tabel $0,05 / 2,15$ $(2,131)$. Dengan demikian Ho ditolak dan Ha diterima. Artinya Risiko Likuiditas berpengaruh positif signifikan terhadap Tingkat Pengembalian Aset pada perusahaan perbankan BUMN periode 2015 - 2019. Penelitian ini sejalan dengan penelitian terdahulu yang dilakukan oleh Suryani (2020), Peling (2018), dan Korompis (2020) bahwa secara parsial risiko likuiditas berpengaruh positif signifikan terhadap tingkat pengembalian aset.

Secara parsial risiko operasional berpengaruh negatif signifikan terhadap Tingkat Pengembalian Aset pada perusahaan BUMN periode 2015 - 2019. Kondisi ni ditunjukkan oleh arah variabel Beta $\mathrm{X}_{4}$ yaitu -0,079, artinya ada pengaruh negatif risiko operasional terhadap ROA, jika risiko operasional meningkat $1 \%$ maka ROA akan menurun $0,079 \%$. Tingkat signifikan koefisien pengaruh parsial ini diuji dengan uji $t$, yang menunjukkan hasil nilai $t_{\text {hitung }}$ sebesar -9,778 dengan nilai sig sebesar 0,00 Dengan menggunakan uji 2 arah, diperoleh $t$ tabel 2,131 hal ini menunjukkan bahwa nilai t hitung - 9,778 lebih kecil dari pada nilai t tabel $0,05 / 2,15$ ( 2,131 ). Dengan demikian Ho ditolak dan Ha diterima. Artinya Risiko Operasional berpengaruh negatif signifikan terhadap Tingkat Pengembalian Aset pada perusahaan BUMN periode 2015 - 2019. Penelitian ini sejalan dengan penelitian terdahulu yang dilakukan oleh Buchory (2020), Wahyuni (2016), Fathoni (2017) bahwa secara parsial risiko operasional berpengaruh signifikan terhadap tingkat pengembalian aset.

\section{Simpulan}

1. Berdasarkan Surat Edaran BI No. 6/23/DPNP/2014 Kinerja Perusahaan Perbankan untuk setiap Risk Profile sbb: (a) rasio NPL sebagai indikator Risiko Kredit menunjukkan kinerja perbankan BUMN; dalam posisi sehat selama periode 2015 - 2019; (b) rasio NIM sebagai indikator Risiko Pasar menunjukkan kinerja perbankan BUMN dalam posisi sangat sehat selama periode 2015 - 2019; (c) rasio LDR sebagai indikator Risiko Likuiditas menunjukkan kinerja perbankan; (d) BUMN dalam posisi cukup sehat selama periode 2015 - 2019; (e) rasio BOPO sebagai indikator Risiko Operasional menunjukkan kinerja perbankan; dan (f) BUMN dalam posisi sangat sehat selama periode 2015 - 2019.

2. Secara simultan Risiko Kredit, Risiko Pasar, Risiko Likuiditas dan Risiko Operasional berpengaruh positif signifikan terhadap Tingkat Pengembalian Aset Pada Perusahaan Perbankan BUMN selama periode 2015 - 2019. Artinya peningkatan Risiko Kredit, Risiko Pasar, Risiko Likuiditas dan Risiko Operasional secara simultan berpengaruh positif signifikan terhadap Tingkat Pengembalian Aset.

3. Secara parsial Risiko Kredit (NPL) berpengaruh negatif tidak signifikan terhadap. Tingkat Pengembalian Aset. Secara parsial Risiko Pasar (NIM) berpengaruh positif signifikan terhadap Tingkat Pengembalian Aset. Artinya kenaikan Risiko Pasar mengakibatkan Tingkat Pengembalian Aset meningkat. Secara parsial Risiko Likuiditas (LDR) berpengaruh positif signifikan terhadap Tingkat Pengembalian Aset. Artinya kenaikan Risiko Likuiditas mengakibatkan Tingkat Pengembalian Aset meningkat. Secara parsial Risiko Operasional (BOPO) berpengaruh 
Muhammad Ridho Almuhdhor, Analisis Risk Profile dan Pengaruhnya Terhadap Tingkat Pengembalian Aset pada Perusahaan Perbankan BUMN yang Terdaftar Di Bursa Efek Indonesia Periode 2015 - 2019

negatif signifikan terhadap Tingkat Pengembalian Aset. Artinya kenaikan Risiko Operasional mengakibatkan Tingkat Pengembalian Aset menurun.

\section{Daftar Pustaka}

A Kadim, K., Nardi, S., Hendro, W., Dessy, A., \& Endang, K. (2018). The Effects Of Bank Soundness With The RGEC Approach (Risk Profile, Good Corporate Governance, Earnings, Capital) Of Leverage And Its Implications On Company's Value Of State Bank In Indonesia For The Period Of 2012-2016.). IJER (International Journal of Economic Research), 15(11), 41-52. http://repository.upi-yai.ac.id/id/eprint/155

Algifari.(2011). Analisis Regresi, Kasus dan Solusi.Edisi kedua. Yogyakarta: BPFE

Damayanti, N. F. (2016). Analisis Kesehatan Bank Dengan Menggunakan Metode Risk Profile, Good Corporate Governance, Earning, Capital (RGEC) Pada PT. BPR Delta Malang Cabang Batu, Doctoral dissertation, University of Muhammadiyah Malang).

Darmawi, H. (2011). Manajemen Perbankan. Jakarta : PT Bumi Aksara

Defri. (2012) Pengaruh Capital Adequency Ratio (CAR), Likuiditas dan Efisiensi Operasional Terhadap Profitabilitas Perusahaan Perbankan yang Terdaftar di BEI. Jurnal Manajemen, 1(1): 1-18

Dewi, M., 2018. Analisis Tingkat Kesehatan Bank Dengan Menggunakan Pendekatan RGEC (Risk Profile, Good Corporate Governance, Earnings, Capital) (Studi Pada PT. Bank Rakyat Indonesia, TBK Periode 2013-2017). Niagawan, 7(3), p.67.Available at: http://dx.doi.org/10.24114/niaga.v7i3.11602.

Diarto, A. P. (2016). Analisis Tingkat Kesehatan Bank Dengan Menggunakan Metode Rgec (Risk Profile, Good Corporate Governance, Earning, Capital)(Study Pada Pt. Bank Rakyat Indonesia (Persero), Tbk Periode 20112014). Jurnal Ilmiah Mahasiswa FEB, 4(2).

Fahmi. (2014). Analisis Laporan Keuangan .Bandung : PT. Raja Grafindo Persada . (2016). Pengantar Manajemen Keuangan. Bandung : Alfabeta

Fahrul, M., \& Rusliati, E. (2016). Credit Risk, Market Risk, Operational Risk and Liquidity Risk on Profitability of Banks in Indonesia http://dx.doi.org/10.23969/trikonomika.v15i2.387

Febrina, R., \& NP, M. W. E. (2016). Analisis Tingkat Kesehatan Bank Umum Berdasarkan Risk Profile, Good Corporate Governance, Earning, Dan Capital (Studi pada Bank Umum yang Terdaftar di Bursa Efek Indonesia Periode 2013-2015). Jurnal Administrasi Bisnis, 37(1), 196-205.

Ghozali. (2018). Aplikasi Analisis Multivariate Dengan Program IBM.SPSS 25.Semarang : Badan Penerbit Universitas Diponegoro

J. \& Lilianti, E., 2019.Analisis Komparatif Kinerja Keuangan dengan Metode Risk Profile, Good Corporate Governance, Earning, Capital (RGEC) pada Bank Umum Pemerintah di Bursa Efek Indonesia. Jurnal Media Wahana Ekonomika, 15(3), p.27. Available at: http://dx.doi.org/10.31851/jmwe.v15i3.2887.

Kasmir. (2014). Analisis Laporan Keuangan.Edisi Pertama.Cetakan Ketujuh. Jakarta: PT. Raja Grafindo Persada . (2016). Analisis Laporan Keuangan. Jakarta: PT. Raja Grafindo Persada (2018). Manajemen Sumber Daya Manusia (Teori dan Praktik).Depok : PT. Raja Grafindo

Luayyi, S., 2019. Analisis Risk Profile, Good Corporate Governance, Earning, Capital Guna Menilai Tingkat Kesehatan Bank. Jurnal Analisa Akuntansi dan Perpajakan, 2(2).Available at: http://dx.doi.org/10.25139/jaap.v2i2.1394.

Lukmawijaya, A. \& Kim, S.S., 2015.Bank Diversification Effects on Bank Performance and Risk Profile of Bank in Indonesia.DeReMa (Development Research of Management) Jurnal Manajemen, 10(1), pp.74-84.Available at: http://dx.doi.org/10.19166/derema.v10i1.158.

Mosey, Angela Christin, Parengkuan Tommy dan Victoria Untu. 2018. Pengaruh Risiko Pasar dan Risiko Kredit terhadap Profitabilitas pada Bank Umum BUMN yang Terdaftar di BEI periode 2012-2016. Jurnal EMBA. Vol.6., No.3. Hal:1338-1347. https://doi.org/10.35794/emba.v6i3.20217

Nazir. (2013). Metodologi Penelitian. Bogor : Ghalia Indonesia

Noor, Juliansyah. (2014). Analisis Data Penelitian Ekonomi dan Manajemen. Jakarta : Grasindo

Rivai dkk.(2012) Kepemimpinan dan Perilaku Organisasi Edisi Ketiga.Jakarta : PT Rajagrafindo Persada

Saeed, M. H. (2015). Examining the relationship between operational risk, credit risk and liquidity risk with performance of Malaysia banks http://etd.uum.edu.my/4631

Sugiono. (2010). Metode Penelitian Pendidikan Pendekatan Kuantitatif, Kualitatif dan R\&D. Bandung : Alfabeta . (2017). Metode Penelitian Pendidikan Pendekatan Kuantitatif, Kualitatif dan R\&D. Bandung: Alfabeta

Sunyoto.(2013). Metodologi Penelitian Akuntansi.Bandung : PT Refika

Sutrisno, M., 2019. GCG disclosure and risk profile on bank performance: case studies on state-owned banks. Proceedings of the 16th International Symposium on Management (INSYMA 2019).Available at: http://dx.doi.org/10.2991/insyma-19.2019.17. 
Veithzal Rivai, Sofyan Basir, Sarwono Sudartono, Arifandy Pertama Veithzal (2013) Commercial Bank Management:Manajemen Perbankan Dari Teori Ke Praktik. Edisi Pertama. Jakarta: PT Raja Grafindo Persada.

Wulandari, R., Mas'ud, I. \& Roziq, A., 2018. Pengaruh Profil Risiko, Tata Kelola dan Permodalan Terhadap Profitabilitas (Studi Bank Umum Konvensional periode 2012-2015). e-Journal Ekonomi Bisnis dan Akuntansi, 5(1), p.88. Available at: http://dx.doi.org/10.19184/ejeba.v5i1.7743.

Yunika, Z., Suhadak, S., \& Topowijono, T. (2017). Analisis Kinerja Keuangan Menggunakan RGEC (Risk Profile, Good Corporate Governance, Earning And Capital) sebagai Metode untuk Mengukur Tingkat Kesehatan Bank (Studi pada Perusahaan Perbankan yang Terdaftar di BEI Periode 2011-2016). Jurnal Administrasi Bisnis, 50(6), 106-111.

Peraturan Bank Indonesia (PBI) Nomor 5 Tahun 2003

Peraturan Bank Indonesia (PBI) Nomor 11/25/2009

POJK No. 42/POJK.03/2015 Tentang Kewajiban Pemenuhan Rasio Kecukupan Likuiditas (Liquidity Coverage Ratio) bagi Bank Umum.

POJK No. 50/POJK.03/2017 Tentang Kewajiban Pemenuhan Rasio Pendanaan Stabil Bersih (Net Stable Funding Ratio) Bagi Bank Umum.

POJK Nomor 65/POJK.03/2016 Tentang Penerapan Manajemen Ris. 